\title{
Detection of Helicobacter pylori in faeces by culture, PCR and enzyme immunoassay
}

\author{
S. KABIR \\ Academic Research and Information Management, 11736 Stockholm, Sweden
}

\begin{abstract}
Various techniques such as culture, PCR and enzyme immunoassay have been used to detect Helicobacter pylori infection in human faecal specimens. Attempts to culture $H$. pylori have had limited success as the bacterium exists predominantly in a nonculturable (coccoid) form in the faeces. Several PCR protocols, differing from each other in the choice of genomic targets and primers, have been used to detect $H$. pylori infection. Substances in faeces that inhibit PCR have been removed by various pre-PCR steps such as filtration through a polypropylene membrane, biochemical separation by column chromatography and isolation of $H$. pylori with immunomagnetic beads, the former two techniques yielding results with a high degree of sensitivity and specificity. An enzyme immunoassay based on the detection of $H$. pylori antigen in faeces has become a convenient tool for the pre-treatment diagnosis of the infection. The stool antigen assay is convenient, especially for children, as it involves neither surgery nor the discomfort associated with the urea breath test. However, its applicability in monitoring eradication therapy has been controversial, as the assay can detect dead or partially degraded bacteria long after actual eradication, thus giving false positive results.
\end{abstract}

\section{Introduction}

Helicobacter pylori is a fastidious, gram-negative, flagellate bacterium known to colonise only man [1]. It is recognised as the major cause of gastritis and peptic ulcer and has been classified as a carcinogen class I [2]. Long-term carriage can lead to gastric adenocarcinoma and mucosa-associated lymphoid tissue (MALT) gastric lymphoma [3]. Various tests have been developed to diagnose the infection [4]. H. pylori can be detected by non-invasive and invasive methods, the latter requiring endoscopy. Non-invasive testing for $H$. pylori can be done by measuring exhaled ${ }^{13} \mathrm{C}$-labelled $\mathrm{CO}_{2}$ (known as the urea breath test, UBT), by serology and by analysing body materials such as faeces, saliva and urine [5-9]. However, positive results obtained by serology do not necessarily indicate current infection by $H$. pylori. The UBT requires an expensive instrument such as a mass spectrometer, which is not always available in routine clinical laboratories. Individuals are infected with $H$. pylori world-wide, but the prevalence is very high in economically less developed regions [10]. The presence of $H$. pylori in

Received 4 Dec. 2000; revised version accepted 18 June 2001.

Corresponding author: Dr S. Kabir (e-mail: skabir43@ hotmail.com). faeces is compatible with a faecal-oral route of transmission, as faeces can contaminate the natural water supplies commonly used by people in poorer regions of the world. Faeces contain various materials such as diverse micro-organisms, inorganic compounds (mostly calcium and phosphates), bile salts, polysaccharides, undigested plant fibres, numerous degradative enzymes, mucus and insoluble products of the gastrointestinal tract $[11,12]$. Because of ease of availability, faeces can be a convenient sample for the detection of H. pylori. Faecal testing is particularly appropriate for children as faeces can be obtained from them without their active collaboration, as compared with samples collected by endoscopy or for UBT. Furthermore, the patients can supply the material in the privacy of their homes. A few techniques such as bacterial culture, PCR and enzyme immunoassay have been used to detect $H$. pylori in faeces. The present review attempts to summarise our present knowledge on the detection of $H$. pylori in faeces by these techniques.

\section{Culture}

The most specific method to detect $H$. pylori is culture of the bacterium from the clinical specimen. However, very few investigators have isolated $H$. pylori from faeces $[7,13,14]$. The presence of massive numbers of 
diverse micro-organisms in faeces may make it very difficult for a fastidious bacterium such as $H$. pylori to grow. Thus, H. pylori differs from other easily cultivable enteric bacteria such as Escherichia coli, Shigella spp., Salmonella spp. or Vibrio cholerae [15]. The mechanism by which viable $H$. pylori can be excreted in the faeces is not properly understood. $H$. pylori colonises areas of the stomach which are not in contact with bile [16] and the bacterium is known to be sensitive to bile. As bile is present in the duodenum and the colon [17], the organism may not survive transit through the alimentary tract in association with the faeces.

In a study from the Gambia, $H$. pylori was cultured from fresh faeces of nine of 23 infants between the ages of 3 and 27 months and from the diarrhoeal stool of an adult, suggesting that the faeces of some individuals may contain viable $H$. pylori [13]. A later study showed that Gambian children were malnourished with evidence of reduced gastric acid secretion [18] and thus the Gambian children in the previous study may also have been malnourished [13]. The isolation of $H$. pylori from the faeces of these children may have been possible because $H$. pylori is released in a viable form in the faeces only under special circumstances. Children have a shorter intestinal transit time than adults. Moreover, acute $H$. pylori infection in children has been associated with decreased gastric acid secretion [18]. Investigations with ferrets have revealed that decreased acidity in the stomach may cause enhanced detection of a Helicobacter spp. in the faeces [19]. Therefore, transmission of $H$. pylori through the gut might have taken place in a selected group of Gambian patients who were hypochlorhydric or achlorhydric.

In another study, $H$. pylori was cultured from fresh stool specimens ( $<1 \mathrm{~h}$ after excretion) from 12 of 25 known $H$. pylori-infected patients [7]. This indicates that $H$. pylori may not survive for a long time in the faeces. However, the authenticity of these $H$. pylori isolates has not been established, as they were not tested for oxidase activity and their identity was not established by sequence analysis of the 16S rRNA gene. Man can also be infected with non-pylori Helicobacter species such as H. heilmannii, H. pullorum, $H$. cinaedi and $H$. fennelliae [20]. Clinical isolates cannot be adequately classified on the basis of their shape (i.e., spiral or curved) alone. Phylogenic relationships among bacterial species are best determined by sequence analysis of the 16S rRNA gene and ideally this technique should be used for the proper identification of clinical isolates from faecal specimens.

Recently, Parsonnet et al. [21] were able to cultivate $H$. pylori from $22 \%$ of faecal samples, obtained artificially by a cathartic (i.e., purgative) agent. However, they could not isolate $H$. pylori when normal stools were sampled. Faecal samples obtained artificially with a purgative do not represent the natural conditions of faecal transit. Attempts have been made to inactivate bile acids by treating faecal suspensions from $H$. pylori-infected patients with cholestyramine, a basic anion-exchange resin that binds bile acids [14]. However, H. pylori could be cultured only from the faeces of $5(26 \%)$ of $19 \mathrm{H}$. pylori-infected patients in this study.

Our understanding of the form and viability of $H$. pylori in the faeces is far from complete. The $H$. pylori bacterium is spiral-shaped or a curved rod when observed in vivo [20]. In-vitro experiments have shown that bile acids can alter the morphology of $H$. pylori to a spherical shape [16]. Therefore, it is possible that during its transit through the bile-laden, anaerobic environment of the duodenum and the colon, H. pylori might be converted to the spherical or the coccoid form. In older cultures the bacteria could take the coccoid form, which has been described as a viable and resting form [22]. According to one study, the amount of nucleic acid is significantly reduced in the coccoid form, indicating that this form of $H$. pylori may be the morphological manifestation of bacterial cell death [23]. However, another study found that the DNA composition was similar in two forms, suggesting that the coccoid form was probably viable [24]. A recent study demonstrated that in an anaerobic environment H. pylori exists predominantly in the coccoid form, but a significant proportion of bacterial cells retain viability as judged by acridine orange staining and the accumulation of polyphosphates [25]. The coccoid form of $H$. pylori has been reported to induce gastritis in $\mathrm{BALB} / \mathrm{c}$ mice [26], but these results have not been reproduced in pigs [27], further illustrating the controversy as to the pathological significance of the coccoid form.

\section{PCR}

Molecular tests based upon PCR enable the specific detection of nucleic acid and have been used for the diagnosis of $H$. pylori in clinical specimens. PCR tests for $H$. pylori that use a range of genomic targets have been reviewed recently [28]. Because of its high sensitivity, PCR is suitable for diagnosis when an organism is present in low numbers, slow growing or difficult to identify. However, despite high sensitivity, the technique is susceptible to inhibition by contaminants present in the clinical specimens, thus giving false negative results. Human faeces are known to contain PCR inhibitors, which should be removed from the specimen before target DNA amplification [29]. It has been suggested that the inhibition of PCR can be overcome by dilution of the faecal suspension [30], but this may make the assay less sensitive, as fewer bacteria would be present in the diluted sample. Several procedures have been developed to purify DNA from faeces for PCR amplification. 


\section{Removal of PCR inhibitors by filtration}

DNA prepared from the filtrate, after faecal suspensions were filtered through a polypropylene membrane, did not contain PCR inhibitors [31]. Primers specific for a 411-bp DNA fragment of the ureA gene of $H$. pylori yielded positive results in 44 of $46 \mathrm{H}$. pyloriinfected patients determined by histology (sensitivity 95.6\%) (Table 1) [31]. Faecal specimens from $H$. pylori-free patients yielded negative results (specificity $100 \%$ ). With this method, it was found that the $H$. pylori cagA gene was present in $18(60 \%)$ of 30 faecal samples [32], confirming the observation that c. 60$80 \%$ of $H$. pylori isolates carry the CagA protein, regarded as a virulence factor [33]. Filtration of faecal suspensions through various macroporous membranes other than polypropylene (e.g., nylon, polyester, polyethylene and fluorocarbon) did not remove PCR inhibitors [34]. Xantham gum, a complex polysaccharide, was retained only by the polypropylene filter, indicating that polysaccharides may act as PCR inhibitors. The mechanism of retention of polysaccharides by the polypropylene filter has not been elucidated.

\section{Immunomagnetic separation (IMS)-based PCR}

Paramagnetic beads coated with antibody to surface antigens of $H$. pylori have been used to isolate both the rod and the coccoid forms of $H$. pylori from seeded faecal suspensions [35]. Immunomagnetic separation (IMS) concentrates the bacteria from crude contaminants, thereby reducing the presence of PCR inhibitors. IMS with a monoclonal antibody to urease A has been used to isolate H. pylori from the faeces of Japanese dyspeptic patients with proven $H$. pylori infection [36]. The immunomagnetic bead-bacteria complex was washed to remove PCR inhibitors, treated with a lysis buffer and heated to extract DNA. A primer pair derived from the nucleotide sequence of ureA of $H$. pylori was used to amplify a $411 \mathrm{bp}$ DNA fragment (Table 1) [36]. Thirty-five $(61 \%)$ of $57 \mathrm{H}$. pyloriinfected patients had positive faecal samples. None of the $15 \mathrm{H}$. pylori-negative patients had PCR-positive faecal samples (specificity 100\%).

Paramagnetic beads coated with polyclonal anti- $H$. pylori antibody have been used in the pre-PCR step to isolate $H$. pylori from the faeces of children [37]. DNA was obtained by boiling the bead-bacteria complex. The PCR assay used primers to amplify the 411-bp segment of the H. pylori ureA gene and $41(60 \%)$ of samples from 68 children were positive. PCR has also been used to detect H. pylori in normal (non-cathartic) and artificially induced (cathartic) stool specimens from 16 subjects infected with $H$. pylori. A pair of primers specific for a 139-bp product of the H. pylori 16S rRNA gene detected $H$. pylori DNA in $5(31.3 \%)$ of 16 normal faeces and in $11(68.8 \%)$ of 16 faecal specimens obtained with a cathartic agent [21].

The sensitivity offered by IMS is lower than that obtained with other pre-PCR steps (Table 2). Although IMS is a valuable enrichment technique, it may not remove all PCR inhibitors from the faecal suspensions. $H$. pylori is known to exhibit great genetic diversity, but IMS is antigen specific and is of use only when a particular antigen can be targeted. Therefore, IMS can have only limited application as a pre-PCR step.

\section{Biochemical purification of faecal DNA for PCR}

Chromatography on a Qiagen column containing silica gel has been used to adsorb nucleic acids from the faecal cell lysates [38]. Carbohydrates and proteins are not retained by the matrix and the bound nucleic acids are eluted under low salt conditions. A pair of primers based on the nucleotide sequence of a gene encoding a species-specific 26-kDa protein antigen of $H$. pylori was used to amplify an $H$. pylori DNA fragment ( $c$. $300 \mathrm{bp}$ ). The reaction was modified by a semi-nested PCR, which amplified a 209-bp fragment of $H$. pylori DNA in the faeces of 59 of 63 patients with proven infection by histology and culture (93.7\% sensitivity), but in none of the 37 uninfected controls $(100 \%$ specificity). This PCR assay has been used to monitor the efficiency of eradication 1 month after therapy. Of 55 patients, 41 were considered to be $H$. pylori-free and 14 still infected as judged by histology and culture. PCR was positive in 13 (92.9\%) of 14 infected patients. However, PCR was still positive in 21 of $41 \mathrm{H}$. pylorieradicated patients, indicating that 1 month may be too soon after therapy to monitor eradication efficiency. As PCR cannot distinguish between living and dead organisms, the persistence of $H$. pylori DNA arising from dead or partially degraded bacteria might contribute to the observed false positive results.

When faecal extracts were subjected to column chromatography and the eluates were analysed for $H$. pylori DNA by PCR, it was observed that inhibitors in the faeces were complex polysaccharides [39]. These probably originate from vegetable materials in the diet, as faeces from a subject consuming a non-vegetarian diet did not contain PCR inhibitors [40].

Acidic polysaccharides have been found to inhibit PCR [41]. Cetyltrimethyl ammonium bromide (CTAB) has been used to prepare polysaccharide-free DNA for PCR amplification [30,42]. A pair of primers specific for a 109-bp fragment of the 16S rRNA gene of $H$. pylori yielded positive results in 28 of 31 patients with gastritis, a sensitivity of $90 \%$. Faeces from 11 patients who had a normal gastric biopsy were not positive in the assay (specificity 100\%). However, van Zwet et al. [43], with similar techniques, could not detect $H$. pylori DNA in the faeces of $24 \mathrm{H}$. pylori-infected patients with similiar techniques.

A procedure in which lipid solubilisers, detergents (ionic and non-ionic), CTAB and organic solvents were used has been developed to purify faecal DNA [44]. 
Table 1. Conditions for different PCR-based protocols for the identification of $H$. pylori in faeces

\begin{tabular}{|c|c|c|c|c|c|c|}
\hline $\begin{array}{l}\text { Target } \\
\text { gene }\end{array}$ & $\begin{array}{l}\text { Nucleotide } \\
\text { position }\end{array}$ & Primer and sequence $\left(5^{\prime}-3^{\prime}\right)$ & $\begin{array}{l}\text { Product } \\
\text { size }(b p)\end{array}$ & PCR conditions & Amplimer verification & $\begin{array}{l}\text { Ref. } \\
\text { no. }\end{array}$ \\
\hline ureA & $\begin{array}{l}304-321 \\
697-714\end{array}$ & $\begin{array}{l}\text { HPU1: GCCAATGGTAAATTAGTT } \\
\text { HPU2: CTCCTTAATTGTTTTTAC } \\
\text { HPU1-HPU2 }\end{array}$ & 411 & $\begin{array}{l}95^{\circ} \mathrm{C} \text { for } 5 \mathrm{~min}(1 \text { cycle }) ; 94^{\circ} \mathrm{C} \text { for } 1 \mathrm{~min}, 45^{\circ} \mathrm{C} \text { for } 1 \mathrm{~min}, 72^{\circ} \mathrm{C} \\
\text { for } 1 \mathrm{~min}(35 \text { cycles }) ; 72^{\circ} \mathrm{C} \text { for } 7 \mathrm{~min} \\
94^{\circ} \mathrm{C} \text { for } 30 \mathrm{~s}, 45^{\circ} \mathrm{C} \text { for } 90 \mathrm{~s}, 72^{\circ} \mathrm{C} \text { for } 60 \mathrm{~s}(40 \text { cycles }), 72^{\circ} \mathrm{C} \text { for } \\
90 \mathrm{~s}(10 \text { cycles })\end{array}$ & $\begin{array}{l}\text { Gel electrophoresis } \\
\text { Gel electrophoresis }\end{array}$ & $\begin{array}{l}{[31]} \\
{[36]}\end{array}$ \\
\hline $\operatorname{cag} A$ & $\begin{array}{l}2593-2612 \\
2992-2973\end{array}$ & $\begin{array}{l}\text { AATACACCAACGCCTCCAAG } \\
\text { TTGTTGCCGCTTTTGCTCTC }\end{array}$ & 400 & $\begin{array}{l}94^{\circ} \mathrm{C} \text { for } 4 \mathrm{~min}(1 \mathrm{cycle}) ; 94^{\circ} \mathrm{C} \text { for } 1 \mathrm{~min}, 59^{\circ} \mathrm{C} \text { for } 1 \mathrm{~min}, 72^{\circ} \mathrm{C} \\
1 \mathrm{~min}(35 \text { cycles }), 72^{\circ} \mathrm{C} \text { for } 10 \mathrm{~min}\end{array}$ & RFLP of PCR products & [32] \\
\hline SSA & $\begin{array}{l}474-496 \\
776-754 \\
474-496 \\
682-652\end{array}$ & $\begin{array}{l}\text { Primer 3: TGGCGTGTCTATTGACAGCGAGC } \\
\text { Primer 4: CCTGCTGGGCATACTTCACCATG } \\
\text { Semi-nested PCR } \\
\text { Primer 3 } \\
\text { TGATCACTGCATGTCTTACTTTCATGTTTTT }\end{array}$ & 209 & $\begin{array}{l}98^{\circ} \mathrm{C} \text { for } 10 \mathrm{~min}(1 \mathrm{cycle}) ; 92^{\circ} \mathrm{C} \text { for } 30 \mathrm{~s}, 68^{\circ} \mathrm{C} \text { for } 1 \mathrm{~min}(1 \mathrm{cycle}) ; \\
92^{\circ} \mathrm{C} \text { for } 30 \mathrm{~s}, 68^{\circ} \mathrm{C} \text { for } 1 \mathrm{~min}(37 \mathrm{cycles}) ; 72^{\circ} \mathrm{C} \text { for } 2 \mathrm{~min} \\
(6 \text { cycles }) \\
94^{\circ} \mathrm{C} \text { for } 5 \mathrm{~min}(1 \mathrm{cycle}) ; 94^{\circ} \mathrm{C} \text { for } 30 \mathrm{~s}, 68^{\circ} \mathrm{C} \text { for } 1 \mathrm{~min}, 72^{\circ} \mathrm{C} \text { for } \\
45 \mathrm{~s}(30 \text { cycles }), 72^{\circ} \mathrm{C} \text { for } 5 \mathrm{~min}\end{array}$ & $\begin{array}{l}\text { Dot-blot hybridisation with a } \\
\text { biotinylated DNA probe }\end{array}$ & [38] \\
\hline \multirow[t]{2}{*}{ 16S rRNA } & $\begin{array}{l}834-853 \\
744-763\end{array}$ & $\begin{array}{l}\text { Hp1: CTGGAGAGACTAAGCCCTCC } \\
\text { Hp2: ATTACTGACGCTGATTGTGC } \\
\text { Hp1-Hp2 }\end{array}$ & 110 & $\begin{array}{l}95^{\circ} \mathrm{C} \text { for } 30 \mathrm{~s}, 55 / 60^{\circ} \mathrm{C} \text { for } 30 \mathrm{~s}, 72^{\circ} \mathrm{C} \text { for } 30 \mathrm{~s}(20 / 30 / 40 \text { cycles }) \text {, } \\
72^{\circ} \mathrm{C} \text { for } 5 \mathrm{~min} \\
94^{\circ} \mathrm{C} \text { for } 2 \mathrm{~min}, 60^{\circ} \mathrm{C} \text { for } 30 \mathrm{~s}, 72^{\circ} \mathrm{C} \text { for } 1 \mathrm{~min}(1 \mathrm{cycle}), 94^{\circ} \mathrm{C} \text { for } \\
30 \mathrm{~s}, 60^{\circ} \mathrm{C} \text { for } 1 \mathrm{~min}, 72^{\circ} \mathrm{C} \text { for } 1 \mathrm{~min}(39 \text { cycles }), 72^{\circ} \mathrm{C} \text { for } \\
5 \mathrm{~min}\end{array}$ & $\begin{array}{l}\text { Gel electrophoresis } \\
\text { Southern blot with a } \\
\text { digoxigenin-labelled 20- } \\
\text { mer oligo probe }\end{array}$ & $\begin{array}{l}{[42]} \\
{[43]}\end{array}$ \\
\hline & $\begin{array}{l}691-710 \\
829-809\end{array}$ & $\begin{array}{l}\text { GCGACCTGCTGGAACATTAC } \\
\text { CGTTAGCTGCATTACTGGAGA }\end{array}$ & 139 & $\begin{array}{l}95^{\circ} \mathrm{C} \text { for } 30 \mathrm{~s}, 60^{\circ} \mathrm{C} \text { for } 1 \mathrm{~min}, 70^{\circ} \mathrm{C} \text { for } 1 \mathrm{~min}(40 \text { cycles }), 70^{\circ} \mathrm{C} \\
\text { for } 5 \mathrm{~min}\end{array}$ & $\begin{array}{l}\text { Southern blot with a }\left[{ }^{32} \mathrm{P}\right]- \\
\text { labelled 16-mer oligo } \\
\text { probe }\end{array}$ & [44] \\
\hline $\begin{array}{l}\text { DNA } \\
0.86 \mathrm{~kb}\end{array}$ & & $\begin{array}{l}\text { EHC-U: CCCTCACGCCATCAGTCCCAAAAA } \\
\text { EHC-L: AAGAAGTCAAAAACGCCCCAAAAC }\end{array}$ & 417 & $\begin{array}{l}94^{\circ} \mathrm{C} \text { for } 45 \mathrm{~s}, 59^{\circ} \mathrm{C} \text { for } 30 \mathrm{~s}, 72^{\circ} \mathrm{C} \text { for } 45 \mathrm{~s}(30 \text { cycles }), 72^{\circ} \mathrm{C} \text { for } \\
10 \mathrm{~min}\end{array}$ & $\begin{array}{l}\left.\text { Southern blot with a }{ }^{32} \mathrm{P}\right]- \\
\text { labelled } 0.86-\mathrm{kb} \text { DNA } \\
\text { probe }\end{array}$ & [46] \\
\hline
\end{tabular}


Table 2. Comparison of various pre-PCR steps for the detection of $H$. pylori

\begin{tabular}{llccc}
\hline Pre-PCR step* & Target gene & Sensitivity & Specificity & Ref. no. \\
\hline $\begin{array}{c}\text { Removal of PCR inhibitors } \\
\text { by a polypropylene filter }\end{array}$ & ureA & 95.6 & 100 & 31 \\
$\begin{array}{c}\text { Isolation of } H \text {. pylori with } \\
\text { immunomagnetic beads }\end{array}$ & ureA & 61.0 & 100 & 36 \\
$\begin{array}{c}\text { DNA purification by various } \\
\text { biochemical techniques }\end{array}$ & $\begin{array}{l}\text { Species-specific } \\
\text { antigen (26 kDa) }\end{array}$ & 93.7 & 100 & 38 \\
& $\begin{array}{l}\text { gene } \\
\text { 16S rRNA (bp 110) }\end{array}$ & 90.0 & 100 & 42 \\
& $\begin{array}{l}\text { 16S rRNA (bp 139) } \\
\text { 0.86 kb DNA }\end{array}$ & 73.0 & 100 & 44 \\
& 25 & 90 & 46 \\
\hline
\end{tabular}

* Major steps involved in the purification of DNA.

†DNA purified by column chromatography and concentrated over a Microcon filter.

DNA purified by CTAB

${ }^{\S}$ DNA isolated by the use of lipid solubilisers, ionic and non-ionic detergents.

PCR amplification was performed with a pair of primers specific for the 139-bp oligonucleotide of the $H$. pylori 16S rRNA gene. The fragment was detected in 8 of 11 patients with proven $H$. pylori infection by histology (sensitivity 73\%). Subjects without infection did not produce any positive PCR results (specificity of $100 \%)$. This procedure for the isolation of DNA is lengthy and labour-intensive. Furthermore, it produces results with a lower sensitivity than those obtained by other pre-PCR steps (Table 2). Although CTAB has been used to remove faecal polysaccharides, the possibility that it can degrade DNA has also been raised [45].

\section{Other PCR strategies}

PCR has been used to identify $H$. pylori DNA indirectly in faecal samples by culture of stool specimens and then amplification of an $H$. pylori DNA fragment in the isolated bacterial cultures [7]. H. pylori was cultured from the faeces of 12 of 25 patients with proven infections. Primers specific for the ureA gene of H. pylori could amplify a 411-bp fragment in cultures from three patients, while DNA from two of these isolates was amplified by primers specific for the $\operatorname{cag} A$ gene.

At times, the detection rate of $H$. pylori DNA by PCR in faecal samples has been poor [46]. HindIII-digested DNA fragments derived from an EcoRI-digested 6.5-kb fragment of chromosomal $H$. pylori DNA were cloned into a plasmid. A pair of 24-base nucleotide primers, selected from the sequence data of the $0.86-\mathrm{kb}$ DNA fragment, amplified a product of $417 \mathrm{bp}$ from the genomic DNA of $H$. pylori. The primer pair detected H. pylori DNA in only $15(25 \%)$ of 61 patients with infections proven by histology. The reason behind this poor performance has not been explained. Although several primer pairs for different genomic targets of $H$. pylori have been used, conflicting and variable results have been obtained with the same primer pair in different laboratories [28]. Therefore, it is advisable to use at least two sets of primers that target different genes for PCR-based detection of $H$. pylori in faeces.

\section{Stool antigen enzyme immunoassay (Premier Platinum HpSA)}

A commercial kit based on an enzyme-linked immunosorbent assay (ELISA) that detects $H$. pylori antigen in stool specimens has been marketed recently (Premier Platinum HpSA Test, Meridian Diagnostics, USA; US patent no. 5716791). To circumvent the problem of strain variation in $H$. pylori, the kit manufacturer has selected one $H$. pylori strain, which can be found in different geographic regions and dietary groups [47]. Bacterial sonicates were prepared and the supernate obtained after centrifugation was used to immunise rabbits. The resulting polyclonal anti- $H$. pylori antibody is adsorbed to the microwells of ELISA plates and forms the basis of a capture assay. Diluted stool samples and a peroxidase-conjugated polyclonal anti- $H$. pylori antibody are added and, after incubation and routine washing, enzyme substrate is added to the wells and the resulting colour change is measured.

The stool antigen assay ( $\mathrm{HpSA}$ ) has produced promising results for the detection of $H$. pylori in faecal samples. A prospective multicentre European study evaluated the accuracy of HpSA for active $H$. pylori infection in 501 patients [48]. The results were compared to those obtained with (a) invasive tests requiring endoscopy (rapid urease test, histology, culture) and (b) the non-invasive UBT. The sensitivity and specificity of HpSA were $94.1 \%$ and $91.8 \%$, respectively, whereas those offered by the UBT were $95.3 \%$ and $97.7 \%$, respectively. Several studies with HpSA in various regions of the world have shown comparable sensitivities $(91-98 \%)$ and specificities $(83-100 \%)$ [49-57].

Most $H$. pylori infections are acquired during child- 
hood or adolescence and $90 \%$ of children with duodenal ulcers are infected [58]. Although the UBT has been used to detect $H$. pylori in children, it is not ideal as some children do not co-operate to exhale ${ }^{13} \mathrm{CO}_{2}$ on request. Gastric biopsy samples can be taken from children by endoscopy, but the procedure may necessitate sedation or general anaesthesia. Therefore HpSA appears to provide an attractive method for the detection of $H$. pylori in children. In one study involving 53 children, the performance of HpSA was compared with six other diagnostic tests (UBT, culture, biopsy urease test, histology, serology and PCR) [59]. The diagnostic accuracy of HpSA was comparable (sensitivity $92.6 \%$, specificity $100 \%$ ) to the other tests. Similar detection rates with high sensitivities (85$92 \%)$ and specificities (82-98\%) in paediatric populations have also been reported from a few laboratories [60-62]. These results suggest that HpSA has the potential to diagnose $H$. pylori infection in children. When this assay was used on a number of Turkish children living in Germany, it was found that the acquisition of $H$. pylori infection occurred mainly in the first 2 years of life [63].

HpSA has been used in a few studies to monitor the efficacy of eradication therapy. In a European multicentre study, 279 of 501 patients were found to be $H$. pylori positive and 162 of them received eradication therapy [64]. Four weeks after completing therapy, patients were examined by oesophago-gastroduodenoscopy (EGD) with biopsies, UBT and HpSA. The results of EGD-based methods, used as the gold standard, showed that $H$. pylori infection in 130 of the 162 treated patients had been eradicated. HpSA was negative in 125 and UBT was negative in 129 of the 130 patients. A total of 32 patients remained H. pyloriinfected as judged by EGD-based methods. HpSA was positive in 30 and UBT was positive in 29 of the 32 patients. These results demonstrate the sensitivity and specificity of $\mathrm{HpSA}$ for the accurate detection of eradication as $93.8 \%$ and $96.9 \%$, respectively. A group of 112 Japanese peptic ulcer patients was monitored 4 weeks after the end of eradication therapy [65]. Results for H. pylori detection were negative in 102 and 103 patients by HpSA and UBT, respectively, indicating potential for HpSA as a means of monitoring eradication therapy. Similar promising results 4 weeks after eradication therapy have also been reported in a German study [55]. However, several other studies have questioned the efficacy of HpSA in monitoring eradication therapy. In one study involving 270 patients, 116 who were infected with $H$. pylori underwent gastroscopy (histology and rapid urease test) and UBT after treatment [53]. Stool specimens from these patients were analysed by HpSA. Two months after anti- $H$. pylori therapy, HpSA gave false positive results in 13 patients. Twelve of these 13 patients underwent a further UBT and HpSA 2-6 months after the first evaluation. Nine of the 12 patients were still HpSA positive, while 11 of 12 were UBT negative.
In another study, the efficiency of eradication therapy after 1 month was monitored by HpSA [38]. Of 55 patients, 41 were considered to be $H$. pylori-free and 14 still infected as judged by histology and culture. HpSA gave positive results for $12(85.7 \%)$ of the 14 infected patients. However, positive results were also obtained for 13 of the $41 \mathrm{H}$. pylori-free patients by HpSA, indicating that 1 month may be too soon after treatment to monitor eradication efficiency. False positive results are less common with specimens obtained 8 and 12 weeks after the end of the treatment [66].

In another study, HpSA displayed high sensitivity $(89.5 \%)$ for the diagnosis of $H$. pylori infection, but low specificity $(77.8 \%)$ [67]. The specificity increased to $83.3 \%$, with no change in sensitivity, when the investigators used a higher absorbance cut-off level than that recommended by the manufacturer. When used to monitor eradication therapy, the sensitivity of the test was $70.4 \%$ and $50 \%$ at 6 weeks and 6 months after treatment, respectively. These results indicate that HpSA may not reliably predict the outcome of the eradication treatment. Factors such as the persistence of $H$. pylori coccoid forms or degenerating forms of dead bacteria, or cross-reactivity with other strains of Helicobacter that colonise humans may contribute to the high rate of false positive results.

\section{Limitations and advantages of HpSA}

The HpSA test is qualitative and no quantitative interpretation should be attempted. The results should be studied in conjunction with other diagnostic procedures. The test should not be done on patients who have taken medications containing antimicrobial agents, proton pump inhibitors and bismuth preparations, as these substances may suppress the growth of H. pylori and cause false-negative results. The test has not been validated for use on watery diarrhoeal stools. According to the manufacturer, the assay has been found to be specific for $H$. pylori and did not give false positive results when stool samples were spiked with a number of other enteric micro-organisms. However, it has not been tested against non-pylori urease-positive Helicobacter spp. other than H. pylori that are found in the human stomach. What the test actually detects in the faeces has not been elucidated. It is possible that it detects both living or dead $H$. pylori, or both, or partially digested bacteria from the stomach.

The test is suitable for pre-treatment diagnosis as well as for epidemiological studies. The colour developed by the test can even be monitored visually (sensitivity 94\%, specificity 99\%) [68]. Many patients infected with $H$. pylori are treated by general practitioners and, as HpSA is easy to perform and patient friendly, it is suitable for side-room use. It is cheaper than the noninvasive UBT and its cost is similar to those of serological tests [69]. 
Table 3. Advantages and limitations of diagnostic tests for the detection of H. pylori in the faeces

\begin{tabular}{|c|c|c|}
\hline Diagnostic test & Advantages & Limitations \\
\hline Culture & $\begin{array}{l}\text { Maximum specificity and accuracy in identification } \\
\text { Easily set up in medical laboratories } \\
\text { Permits strain typing } \\
\text { Antimicrobial susceptibility testing possible }\end{array}$ & $\begin{array}{l}\text { Very difficult to culture from the faeces } \\
\text { Limited information on the form and viability of } H \text {. pylori } \\
\text { in the faeces } \\
\text { Delayed result }\end{array}$ \\
\hline PCR & $\begin{array}{l}\text { High sensitivity and specificity } \\
\text { Low numbers of organisms detectable } \\
\text { Quick results possible } \\
\text { Detection of } \operatorname{cag} A \text {-positive strains possible }\end{array}$ & $\begin{array}{l}\text { Removal of PCR inhibitors from the faecal samples } \\
\text { required } \\
\text { Susceptible to contamination } \\
\text { Distinction between live and dead organisms not possible } \\
\text { Persistence of } H \text {. pylori DNA in the faeces may give } \\
\text { false positive results in monitoring early eradication } \\
\text { therapy } \\
\text { Not suitable in the routine clinical setting }\end{array}$ \\
\hline $\begin{array}{l}\text { Stool antigen enzyme } \\
\text { immunoassay (HpSA) }\end{array}$ & $\begin{array}{l}\text { Patient friendly } \\
\text { Convenient for pre-treatment diagnosis as high } \\
\text { sensitivity and specificity are attainable } \\
\text { Excellent epidemiological tool } \\
\text { Quick results possible } \\
\text { Easily set up in medical laboratories } \\
\text { Results can be monitored visually }\end{array}$ & $\begin{array}{l}\text { Monitoring eradication therapy remains controversial } \\
\text { The assay may detect both living and dead, or } \\
\text { partially degraded bacteria } \\
\text { Not suitable for identifying cagA-positive } H \text {. pylori } \\
\text { infection }\end{array}$ \\
\hline
\end{tabular}

\section{Stool antigen enzyme immunoassay (FemtoLab H. pylori)}

Another stool enzyme immunoassay kit, manufactured by FemtoLab H. pylori of Germany, uses monoclonal antibodies against $H$. pylori antigens. The assay showed sensitivity and specificity of $98 \%$ and $96.7 \%$, respectively, in diagnosing $H$. pylori infection [66]. It produced a specificity for eradication therapy of $96.9 \%$ with specimens obtained 4 weeks after the treatment. This value increased to $100 \%$ with stool samples collected 6 and 8 weeks after the end of treatment, as no false positive results were obtained. However, more multicentre-based studies are needed to establish the acceptability of this kit.

\section{Conclusions}

Non-invasive tests on faecal samples can play an important role in the diagnosis of $H$. pylori infections. The advantages and limitations of various tests for the clinical identification of $H$. pylori in the faeces have been summarised in Table 3. Culture should be regarded as the most specific test for the presence of H. pylori. The major advantage of culture as a diagnostic tool is that the isolation of the organism can assist in the choice of antibiotic treatment. However, the success rate for the isolation of $H$. pylori from faeces has been rather poor, and little information is available on the form and viability of $H$. pylori in the faeces. PCR, a powerful method known for its high sensitivity, can detect low numbers of $H$. pylori present in specimens such as the faeces, but faeces are known to contain PCR inhibitors and this limits the direct application of PCR to faecal samples. Among various methods developed to remove PCR inhibitors, filtration of the faecal suspensions through a polypropylene membrane appears to be effective. However, more multicentre studies are needed before it can be recommended. Although PCR has been used to follow up eradication therapy, the persistence of $H$. pylori DNA yields false positive results and restricts its use for early monitoring of treatment efficacy. PCR requires specialised laboratory facilities for its execution and is not generally available as a routine diagnostic tool. The stool antigen assay (HpSA) is a convenient pre-treatment diagnostic test. Results can be monitored visually, thus making it very useful for a general practitioner. However, there are controversies over its use in eradication therapy, especially at an early stage after treatment. Therefore, a simple and reliable test that can be used to monitor eradication treatment, for both short and long periods, is still required.

\section{References}

1. Farthing MJG. Helicobacter pylori infection: an overview. $\mathrm{Br}$ Med Bull 1998; 54: 1-6.

2. NIH Consensus Development Panel on Helicobacter pylori in peptic ulcer disease. Helicobacter pylori in peptic ulcer disease. JAMA 1994; 272: 65-69.

3. The Eurogast Study Group. An international association between Helicobacter pylori infection and gastric cancer. Lancet 1993; 341: 1359-1362.

4. Glupczynski Y. Microbiological and serological diagnostic tests for Helicobacter pylori: an overview. Br Med Bull 1998; 54: $175-186$.

5. Logan RPH, Polson RJ, Misiewicz JJ et al. Simplified single sample ${ }^{13}$ Carbon urea breath test for Helicobacter pylori: comparison with histology, culture, and ELISA serology. Gut 1991; 32: 1461-1464.

6. Sobala GM, Crabtree JE, Pentith JA et al. Screening dyspepsia by serology to Helicobacter pylori. Lancet 1991; 338: 94-96.

7. Kelly SM, Pitcher MCL, Farmery SM, Gibson GR. Isolation of Helicobacter pylori from feces of patients with dyspepsia in the United Kingdom. Gastroenterology 1994; 107: 1671-1674.

8. Patel P, Mendall MA, Khulushi S et al. Salivary antibodies to Helicobacter pylori: screening dyspeptic patients before endoscopy. Lancet 1994; 344: 511-512. 
9. Yamamoto S, Uemura N, Okamoto S, Yamaguchi S, Mashiba $\mathrm{H}$, Tachikawa T.A new rapid test for detecting anti-Helicobacter pylori antibody excreted into urine. Helicobacter 2000; 5: $160-164$.

10. Graham DY, Adam E, Reddy GT et al. Seroepidemiology of Helicobacter pylori infection in India. Comparison of developing and developed countries. Dig Dis Sci 1991; 36: 1084-1088.

11. Ganong WF. Review of medical physiology, 12th edn. Los Altos, CA, Lange Medical Publications. 1985: 417.

12. Sidransky D, Tokino T, Hamilton SR et al. Identification of ras oncogene mutations in the stool of patients with curable colorectal tumors. Science 1992; 256: 102-105.

13. Thomas JE, Gibson GR, Darboe MK, Dale A, Weaver LT. Isolation of Helicobacter pylori from human faeces. Lancet 1992; 340: 1194-1195.

14. Dore MP, Osato MS, Malaty HM, Graham DY. Characterization of a culture method to recover Helicobacter pylori from the feces of infected patients. Helicobacter 2000; 5: 165-168.

15. Axon ATR. Review article: is Helicobacter pylori transmitted by the gastro-oral route? Aliment Pharmacol Ther 1995; 9: 585-588.

16. Itoh $\mathrm{M}$, Wada $\mathrm{K}$, Tan $\mathrm{S}$, Kitano $\mathrm{Y}$, Kai J, Makino I. Antibacterial action of bile acids against Helicobacter pylori and changes in its ultrastructural morphology: effect of unconjugated dihydroxy bile acid. J Gastroenterol 1999; 34: 571-576.

17. Hanninen ML. Sensitivity of Helicobacter pylori to different bile salts. Eur J Clin Microbiol Infect Dis 1991; 10: 515-518.

18. Dale A, Thomas JE, Darboe MK, Coward WA, Harding M, Weaver LT. Helicobacter pylori infection, gastric acid secretion, and infant growth. J Pediatr Gastroenterol Nutr 1998; 26 : 393-397.

19. Fox JG, Blanco MC, Yan L et al. Role of gastric $\mathrm{pH}$ in isolation of Helicobacter mustelae from the feces of ferrets. Gastroenterology 1993; 104: 86-92.

20. Owen RJ. Helicobacter - species classification and identification. Br Med Bull 1998; 54: 17-30.

21. Parsonnet J, Shmuey H, Haggerty T. Fecal and oral shedding of Helicobacter pylori from healthy infected adults. JAMA 1999; 282: 2240-2245.

22. Mai U, Geis G, Leying H, Rühl G, Opferkuch W. Dimorphism of Campylobacter pylori. In: Mégraud F, Lamouliatte H (eds) Gastroduodenal pathology and Campylobacter pylori (Excerpta Medica International Congress Series no. 847). Amsterdam, Excerpta Medica. 1989: 29-33.

23. Kusters JG, Gerrits MM, van Strijp JAG, VandenbrouckeGrauls CMJE. Coccoid forms of Helicobacter pylori are the morphologic manifestation of cell death. Infect Immun 1997; 65: $3672-3679$

24. Hua J, Ho B. Is the coccoid form of Helicobacter pylori viable? Microbios 1996; 87: 103-112.

25. Shirai M, Kakada J, Shibata K, Morshed MG, Matsushita T, Nakazawa T. Accumulation of polyphosphate granules in Helicobacter pylori cells under anaerobic conditions. J Med Microbiol 2000; 49: 513-519.

26. Cellini L, Allocati N, Angelucci D et al. Coccoid Helicobacter pylori not culturable in vitro reverts in mice. Microbiol Immunol 1994; 38: 843-850.

27. Eaton KA, Catrenich CE, Makin KM, Krakowka S. Virulence of coccoid and bacillary forms of Helicobacter pylori in gnotobiotic piglets. J Infect Dis 1995; 171: 459-462.

28. Kabir S. The role of PCR in the diagnosis of Helicobacter pylori infections. Rev Med Microbiol 1999; 10: 197-212.

29. Widjojoatmodjo MN, Fluit AC, Torensma R, Verdonk GPHT, Verhoef $J$. The magnetic immuno polymerase chain reaction assay for direct detection of Salmonellae in fecal samples. J Clin Microbiol 1992; 30: 3195-3199.

30. Mapstone NP. The detection of $H$. pylori by the polymerase chain reaction. In: Clayton CL, Mobley HLT (eds) Methods in molecular medicine, Helicobacter pylori protocols. Totowa, NJ, Humana Press. 1997: 31-36.

31. Notarnicola M, Russo F, Cavallini A et al. PCR identification of Helicobacter pylori DNA in faeces from patients with gastroduodenal pathology. Med Sci Res 1996; 24: 785-787.

32. Russo F, Notarnicola M, di Matteo G et al. Detection of Helicobacter pylori cagA gene by polymerase chain reaction in faecal samples. Eur J Gastroenterol Hepatol 1999; 11: 251-256.
33. Tummuru MKR, Cover TL, Blaser MJ. Cloning and expression of a high-molecular-mass major antigen of Helicobacter pylori: evidence of linkage to cytotoxin production. Infect Immun 1993; 61: 1799-1809.

34. Cavallini A, Notarnicola M, Berloco P, Lippolis A, Di Leo A. Use of macroporous polypropylene filter to allow identification of bacteria by PCR in human fecal samples. $J$ Microbiol Methods 2000; 39: 265-270.

35. Enroth H, Engstrand L. Immunomagnetic separation and PCR for detection of Helicobacter pylori in water and stool specimens. J Clin Microbiol 1995; 33: 2162-2165.

36. Watanabe $\mathrm{T}$, Tomita $\mathrm{S}$, Kudo $\mathrm{M}$ et al. Detection of Helicobacter pylori gene by means of immunomagnetic separation-based polymerase chain reaction in feces. Scand $J$ Gastroenterol 1998; 33: 1140-1143.

37. Casswall TH, Nilsson HO, Bergström M et al. Evaluation of serology, ${ }^{13} \mathrm{C}$-urea breath test, and polymerase chain reaction of stool samples to detect Helicobacter pylori in Bangladeshi children. J Pediatr Gastroenterol Nutr 1999; 28: 31-36.

38. Makristathis A, Pasching E, Schütze K, Wimmer M, Rotter ML, Hirschl AM. Detection of Helicobacter pylori in stool specimens by PCR and antigen enzyme immunoassay. J Clin Microbiol 1998; 36: 2772-2774.

39. Monteiro L, Bonnemaison D, Vekris A et al. Complex polysaccharides as PCR inhibitors in feces: Helicobacter pylori model. J Clin Microbiol 1997; 35: 995-998.

40. Monteiro L, Gras N, Vidal R, Cabrita J, Mégraud F. Detection of Helicobacter pylori in human feces by PCR: application of a technique to remove PCR inhibitors. Gut 1999; 45 Suppl 3: A124.

41. Demcke T, Adams RP. The effects of plant polysaccharides and buffer additives on PCR. Biotechniques 1992; 12: 332-334.

42. Mapstone NP, Lynch DAF, Lewis FA et al. PCR identification of Helicobacter pylori in faeces from gastritis patients. Lancet 1993; 341: 447.

43. van Zwet AA, Thijs JC, Kooistra-Smid AMD, Schirm J, Snijder JAM. Use of PCR with feces for detection of Helicobacter pylori infections in patients. J Clin Microbiol 1994; 32: 1346-1348.

44. Gramley WA, Asghar A, Freirson HF, Powell SM. Detection of Helicobacter pylori DNA in fecal samples from infected individuals. J Clin Microbiol 1999; 37: 2236-2240.

45. Fang G, Hammar S, Grumet R. A quick and inexpensive method for removing polysaccharides from plant genomic DNA. Biotechniques 1992; 13: 52-54, 56.

46. Li C, Ha T, Ferguson DA et al. A newly developed PCR assay of $H$. pylori in gastric biopsy, saliva and feces. Evidence of high prevalence of $H$. pylori in saliva supports oral transmission. Dig Dis Sci 1996; 41: 2142-2149.

47. Larka CV, Sui C, Yi A, Kozak KJ. Immunoassay for H. pylori in fecal specimens. US Patent: 5716791, 10 February 1998.

48. Vaira D, Malfertheiner P, Mégraud F et al. Diagnosis of Helicobacter pylori infection with a new non-invasive antigenbased assay. Lancet 1999; 354: 30-33.

49. Chang MC, Wu MS, Wang HH, Wang HP, Lin JT. Helicobacter pylori stool antigen (HpSA) test - a simple, accurate and non-invasive test for detection of Helicobacter pylori infection. Hepatogastroenterology 1999; 46: 299-302.

50. Fanti L, Mezzi G, Cavallero A, Gesu G, Bonato C, Masci E. A new simple immunoassay for detecting Helicobacter pylori infection: antigen in stool specimens. Digestion 1999; 60: $456-460$.

51. Lehmann F, Drewe J, Terracciano L, Stuber R, Frei R, Beglinger C. Comparison of stool immunoassay with standard methods for detecting Helicobacter pylori infection. BMJ 1999; 319: 1409

52. Puspök A, Bakos S, Oberhuber G. A new, non-invasive method for detection of Helicobacter pylori: validity in the routine clinical setting. Eur J Gastroenterol Hepatol 1999; 11: 1139-1142.

53. Trevisani L, Sartori S, Galvani F et al. Evaluation of a new enzyme immunoassay for detecting Helicobacter pylori in feces: a prospective pilot study. Am J Gastroenterol 1999; 94: $1830-1833$.

54. Agha-Amiri K, Mainz D, Peitz U, Kahl S, Leodolter A, Malfertheiner P. Evaluation of an enzyme immunoassay for detecting Helicobacter pylori antigens in human stool samples. Z Gastroenterol 1999; 37: 1145-1149.

55. Braden B, Teuber G, Dietrich CF, Caspary WF, Lembcke B. 
Comparison of new faecal antigen test with ${ }^{13} \mathrm{C}$-urea breath test for detecting Helicobacter pylori infection and monitoring eradication treatment: prospective clinical evaluation. $B M J$ 2000; 320: 148

56. Spirko MA. Stool antigen immunoassay for detection of $H$. pylori infection. J Fam Pract 2000; 49: 265.

57. Vakil N, Affi A, Robinson J, Sundaram M, Phadnis S. Prospective blinded trial of a fecal antigen test for the detection of Helicobacter pylori infection. Am J Gastroenterol 2000; 95: 1699-1701.

58. Macarthur C, Saunders N, Feldman W. Helicobacter pylori, gastroduodenal disease, and recurrent abdominal pain in children. JAMA 1995; 273: 729-734.

59. Ni Y-H, Lin J-T, Huang S-F, Yang J-C, Chang M-H. Accurate diagnosis of Helicobacter pylori infection by stool antigen test and 6 other currently available tests in children. $J$ Pediatr 2000; 136: 823-827.

60. Rothenbacher D, Bode G, Brenner H. Diagnosis of Helicobacter pylori infection with a novel stool antigen-based assay in children. Pediatr Infect Dis J 2000; 19: 364-366.

61. Braden B, Posselt H-G, Ahrens P, Kitz R, Dietrich CF, Caspary WF. New immunoassay in stool provides an accurate noninvasive diagnostic method for Helicobacter pylori screening in children. Pediatrics 2000; 106: 115-117.

62. Shepherd AJ, Williams CL, Doherty CP et al. Comparison of an enzyme immunoassay for the detection of Helicobacter pylori antigens in the faeces with the urea breath test. Arch Dis Child 2000; 83: 268-270.
63. Rothenbacher D, Inceoglu J, Bode G, Brenner H. Acquisition of Helicobacter pylori infection in a high-risk population occurs within the first 2 years of life. J Pediatr 2000; 136: 744-748.

64. Vaira D, Malfertheiner P, Mégraud F et al. Noninvasive antigen-based assay for assessing Helicobacter pylori eradication: a European multicenter study. The European Helicobacter pylori HpSA Study Group. Am J Gastroenterol 2000; 95: 925-929.

65. Ishihara S, Kaji T, Kawamura A et al. Diagnostic accuracy of a new non- invasive enzyme immunoassay for detecting Helicobacter pylori in stools after eradication therapy. Aliment Pharmacol Ther 2000; 14: 611-614.

66. Makristathis A, Barousch W, Pasching E et al. Two enzyme immunoassays and PCR for detection of Helicobacter pylori in stool specimens from pediatric patients before and after eradication therapy. J Clin Microbiol 2000; 38: 3710-3714.

67. Forné M, Domínguez J, Fernández-Banares $\mathrm{F}$ et al. Accuracy of an enzyme immunoassay for the detection of Helicobacter pylori in stool specimens in the diagnosis of infection and post treatment check-up. Am J Gastroenterol 2000; 95: 2200-2205.

68. Oderda G, Rapa A, Ronchi B et al. Detection of Helicobacter pylori in stool specimens by non-invasive antigen enzyme immunoassay in children: multicentre Italian study. BMJ 2000; 320: $347-348$.

69. Trevisani L, Sartori S, Ruina M et al. Helicobacter pylori stool antigen test: clinical evaluation and cost analysis of a new enzyme immunoassay. Dig Dis Sci 1999; 44: 2303-2306. 